\title{
Psychometric properties and validity of the Center for Epidemiological Studies Depression Scale (CES-D) in a population attending an HIV clinic in Cali, Colombia
}

\author{
Héctor Mueses-Marín¹, David Montaño ${ }^{1}$ Jaime Galindo¹, Beatriz Alvarado-Llano,2, \\ Jorge Martínez-Cajas ${ }^{1,2}$ \\ 1 Grupo de Educación y Salud en VIH/SIDA, Corporación de Lucha contra el Sida, Cali, \\ Colombia \\ 2 Division of Infectious Diseases, Department of Medicine, Queen's University, Kingston, \\ Canada
}

Introduction: Depression in people living with HIV/AIDS is associated with poor health outcomes. Despite this, assessment of depressive symptoms is not a routine clinical practice in the care of people with HIV in Colombia. One reason could be the lack of validated depression screening scales for this population.

Objective: To test the reliability and construct validity of the 20- and 10-item-Center for Epidemiological Studies Depression Scale in patients attending an HIV clinic in Cali, Colombia.

Materials and methods: A non-random sample of 105 adults was enrolled. The 20 itemCES-D (CES-D-20) scale was administered twice: At baseline and 2-4 weeks later. We calculated the Cronbach's alpha coefficient and the intraclass correlation coefficient. In addition, we used an exploratory and confirmatory factorial analysis, as well as the item response theory to assess the validity of the scale.

Results: Most participants were men (73\%), with a mean age of 40 years, $53 \%$ of whom had not completed high school. Cronbach's coefficients were 0.92 and 0.94 at baseline and at the second interview, respectively. The intraclass correlation was 0.81 (95\% Cl: 0.72 0.88). Although all 20 items loaded distinctly in 4 factors, 5 items did not load as expected. The structure factor of the CES-D-20 was not confirmed, as 4 items had poor goodness of fit. The CES-D-10 appeared to perform better in this population.

Received: $05 / 04 / 17$

Accepted: $15 / 06 / 18$

Published: 19/06/18

\section{Citation:}

Mueses-Marin H, Montano D, Galindo J, AlvaradoLlano B, Martinez-Cajas J. Psychometric properties and validity of the Center for Epidemiological Studies Depression Scale (CES-D) in a population attending an HIV clinic in Cali, Colombia. Biomédica. 2019;39: 33-45

https://doi.org/10.7705/biomedica.v39i1.3843

Corresponding author:

Héctor F. Mueses-Marín, Carrera 56 № 2-120, Cali, Colombia

Telephone: (572) 5136152 , extension 113

centroinvestigaciones@cls.org.co

Author contributions:

Héctor Mueses-Marín and Beatriz Alvarado-Llano: Conception and design of the study, and analysis and interpretation of data.

David Montaño: Design, acquisition and interpretation of data.

Jaime Galindo and Jorge Martínez-Cajas: Design and interpretation of data.

All authors participated in the drafting of the article and its critical revision.

\section{Financial support:}

The study was funded by Queens University Principal funds (PI: Beatriz Alvarado).

Conflicts of interest:

The authors declare that there is no conflict of interests regarding the publication of this paper.
Conclusions: These results support the reliability and validity of the CES-D-10 instrument to screen for depressive symptoms in people living with HIV in Colombia.

Key words: Psychometrics; depression; reproducibility of results; HIV; acquired immunodeficiency syndrome; adult; Colombia.

Propiedades psicométricas y validez de la escala de depresión del Center for Epidemiological Studies (CES-D) en personas atendidas en una clínica de HIV en Cali, Colombia

Introducción. La depresión en personas con HIV/sida se asocia con resultados negativos para la salud. La evaluación de los síntomas depresivos no es una práctica clínica rutinaria en el cuidado de personas con HIV/sida en Colombia, lo cual puede deberse a la carencia de escalas validadas para la tamización de la depresión en esta población.

Objetivo. Evaluar la reproducibilidad y validez de constructo de dos versiones de la escala de depresión del Center for Epidemiological Studies (CES-D), la de 20 ítems y la de 10 ítems, en personas con HIV/sida atendidas en una clínica de Cali, Colombia.

Materiales y métodos. Se seleccionó una muestra no probabilística de 105 adultos con $\mathrm{HIV} /$ sida. La escala CES-D se utilizó dos veces (línea basal y 2 a 4 semanas después). La consistencia interna fue evaluada con el coeficiente alfa de Cronbach. La reproducibilidad se evaluó con el coeficiente de correlación intraclase. Para verificar la validez del constructo se utilizó un análisis factorial exploratorio y la teoría de respuesta al ítem.

Resultados. El $73 \%$ de la muestra correspondía a hombres, la edad promedio fue de 40 años y el 53 \% tenía baja escolaridad. El coeficiente alfa de Cronbach fue de 0,92 (línea basal) y de 0,94 (segunda entrevista). El coeficiente de correlación intraclase fue de 0,81 $\left(\mathrm{IC}_{95 \%}, 0,72-0,88\right)$. Aunque en cuatro de los factores en la escala de 20 ítems claramente hubo carga factorial, cinco de los ítems no tuvieron un ajuste adecuado. La CES-D de 10 ítems parece funcionar mejor en esta población.

Conclusiones. Los resultados respaldaron la reproducibilidad y la validez de la escala CES-D para la tamización de síntomas depresivos en personas con HIV/sida en Colombia.

Palabras clave: psicometría; depresión; reproducibilidad de los resultados; VIH; síndrome de inmunodeficiencia adquirida; adulto; Colombia. 
Depression has emerged as a significant mental health issue worldwide (1-3), and people living with HIV/AIDS are not an exception. People living with HIV/AIDS are disproportionally affected by depression with a 5 to 10 times higher prevalence than in the general population (4). In North America, approximately half of the people living with HIV/AIDS have significant depressive symptoms and 20 to $25 \%$ of them meet diagnostic criteria for a depressive disorder $(5,6)$ while in low and middle-income countries depression among people living with HIV/AIDS ranges from $10 \%$ to $68 \%$ (7-10). Moreover, depression in people living with HIV/AIDS is a strong predictor of low levels of treatment adherence, poor virologic response, and increased risk of other chronic conditions $(6,11)$. Depression is associated with increased HIV-specific morbidity and earlier mortality despite access to adequate antiretroviral therapy (12-14), and with overall lower quality of life as measured by a decreased concentration span, poor sleep quality, decreased memory, lower motivation, and increased stress (11,15-19). On this basis, the assessment and treatment of depression are essential in the care of people living with HIV/AIDS. Despite its importance, screening for depression is not consistently performed in the routine clinical care of people living with HIV/ AIDS in Colombia. This may be due in part to the lack of validated scales to screen for depression in this population.

The Depression Scale of the Center for Epidemiologic Studies (CES-D) is a widely used screening scale for depression which has been demonstrated to hold construct and concurrent validity in Colombian adolescents and adults (20-22). In the general population, the CES-D original cut-off point for depression was $\geq 16$ points, although in Colombian populations a better trade-off of sensitivity and specificity was found to be $\geq 20$ points (21). The reliability of the original English language scale had alpha coefficients ranging from 0.85 to 0.9 (20-23). In people living with HIV/AIDS, the CES-D preserved its validity in multiple settings (24-27). A cut-off point of $\geq 16$ points has been found to have a sensitivity ranging from $72.7 \%$ to $79.8 \%$ and a specificity ranging from $78.5 \%$ to $83.0 \%$ in different studies (25-28). Shorter CES-D scales have also been validated with the 10 -item version working as efficiently as the 20 -item one (29).

However, inconsistent results have been found for somatic and positive affect items of the CES-D in people living with HIV/AIDS (30-32). This lack of consistency of the scale in several people living with HIV/AIDS populations emphasizes the need for its cross-cultural validation (33). Thus, we tested the reliability and construct validity of the 20 -item and the 10 -item versions of the CES-D (proposed by Zhang, et al.) (29).

\section{Materials and methods}

\section{Study population}

People living with HIV/AIDS followed in an HIV clinic in Cali (Corporación de Lucha contra el Sida) were invited to participate in a validation study of depression, stigma and adherence scales. The Corporación de Lucha contra el Sida clinic is a non-profit organization that provides comprehensive care to people living with HIV/AIDS in Cali and nearby cities in the southwestern part of Colombia.

Participants were invited if they were 18 years of age or older, were able to provide informed consent, and could be on or off antiretroviral therapy. Potential participants were approached at the clinic during regular appointments and a non-random sample of participants was recruited. 
One hundred and nine patients were invited to participate of whom 105 accepted. All participants were asked to attend two visits, two to four weeks apart. Eighty-four of them completed the follow-up at 2 to 4 weeks. The sample size was calculated to obtain 60 participants in each of three groups: One group of participants naïve to antiretroviral therapy (ART), one with less than one year of ART, and the last one with participants with more than one year of ART. After 6 months of recruitment, we were unable to recruit participants to the first group and, thus, recruitment was halted before completing the sample of 180 .

\section{Data collection}

An interviewer conducted face-to-face interviews with each participant. Interviews lasted from 30 minutes to an hour and took place at the Corporación de Lucha contra el Sida in a room that ensured privacy and confidentiality. The baseline questionnaire included data on age (years), sex at birth, sexual orientation (homosexual, bisexual, heterosexual), ethnicity, civil status (married/living with a partner or not), education level, work status, number of dependent children, level of satisfaction with the place of residence, history of incarceration, and lifestyle characteristics such as regular exercise, smoking, frequency of alcohol and drug use, sexual health (sexually active, condom use, etc.). In addition, clinical factors were extracted from the participants' charts: The viral load and T lymphocyte subpopulation levels including CD4/CD8 ratios.

\section{Center for Epidemiological Studies Depression Scale (CES-D)}

The CES-D is a 20 -item scale (23). Each item is scored on a 4-point scale ranging from 0 (rarely/none of the time) to 3 (most/all of the time). Scores on the CES-D range from 0 to 60 with greater scores indicating a greater degree of depressive symptoms. The scale is composed of four dimensions as per the original development: negative affect (items $3,6,9,14,17$, and 18); positive affect (items 4, 8, 10, 12, and 16); somatic (items 1, 2, 5, 7, 11, and 20), and interpersonal (items 13,15, and 19) manifestations of depressive illness.

We used a Spanish translation of the CES-D scale that other authors had previously tested for validity and reliability in different populations $(22,34)$. The cut-off points of 16 and 20 were used to define the presence of depression since previous studies have suggested that such thresholds were discerning for the presence of depression $(21,22,24,25,27,34,35)$. It should be pointed that the 10-item version proposed by Zhang, et al. (29), has demonstrated to have a sensitivity of $91 \%$ and a specificity of $92 \%$, with a cut-off of $\geq 10$ in people living with HIV/AIDS. This version includes items 1, 5, 6, 7, 8, 10,11,12,14, and 20.

\section{Ethical aspects}

The participation in the study was voluntary. We obtained written informed consent from each participant. This study was reviewed and approved by the Research Ethics Boards of both the Corporación de Lucha contra el Sida and Queen's University.

\section{Statistical analyses}

Descriptive statistics were used to summarise the social and clinical characteristics of the sample. The internal consistency reliability was tested using Cronbach's coefficient. Test-retest reliability was assessed using the intraclass correlation coefficient. Construct validity was established using exploratory factorial analysis and confirmatory factor analysis. 
In interpreting the factor pattern, a factor loading $\geq 0.40$ was considered good. In confirmatory factor analysis, model fit was defined as a comparative fit index and a Tucker-Lewis index of 0.95 while the root mean square error of approximation and the standardized root mean square residual were $<0.08(36)$. We further performed an item response theory analysis to establish items with poor fit and to identify the discriminative capacity of the CES-D items (37).

Finally, we examined the construct validity of the scale by comparing social and clinical characteristics of those with 1) CES-D scores $<16$ with those with CES-D scores $\geq 16$; 2) CES-D scores $<20$ with those with CES-D scores $\geq 20$, and 3 ) those with $\geq 10$ points in the shorten version vs $<10$ points. Group comparisons were conducted using t-tests for continuous variables and contingency table chi-square tests for categorical data and the Mann-Whitney test. All analyses were done with Stata/IC version 12, and R, version 3.3.3.

Table 1. Characteristics of people living with HIV/AIDS participating in the study $(n=105)$

\begin{tabular}{|c|c|c|}
\hline & $\mathbf{n}$ & $\%$ \\
\hline \multicolumn{3}{|l|}{ Age (years) } \\
\hline $20-29$ & 17 & 16 \\
\hline $30-39$ & 33 & 31 \\
\hline $40-49$ & 40 & 38 \\
\hline$\geq 50$ & 15 & 14 \\
\hline \multicolumn{3}{|l|}{ Sex } \\
\hline Men & 76 & 72 \\
\hline \multicolumn{3}{|l|}{ Educational level } \\
\hline None or primary & 38 & 37 \\
\hline Secondary & 38 & 36 \\
\hline Technical education & 14 & 13 \\
\hline University (incomplete/complete) & 13 & 13 \\
\hline No data & 2 & 2 \\
\hline \multicolumn{3}{|l|}{ Employment status } \\
\hline Work & 32 & 30 \\
\hline Housekeepers & 11 & 10 \\
\hline Other & 22 & 21 \\
\hline Unemployed & 37 & 35 \\
\hline No data & 3 & 3 \\
\hline \multicolumn{3}{|l|}{ Marital status } \\
\hline Single & 66 & 63 \\
\hline Married/common law marriage & 26 & 25 \\
\hline Widow, separated or divorced & 11 & 11 \\
\hline No data & 2 & 2 \\
\hline \multicolumn{3}{|l|}{ Life styles } \\
\hline Current smoker & 24 & 23 \\
\hline $\begin{array}{l}\text { Recreational drugs in the last three } \\
\text { months (yes) }\end{array}$ & 12 & 11 \\
\hline $\begin{array}{l}\text { Any consumption of alcohol in the last } 30 \\
\text { days (yes) }\end{array}$ & 44 & 42 \\
\hline Tattoos (yes) & 28 & 27 \\
\hline Ever been arrested (yes) & 22 & 21 \\
\hline \multirow[t]{2}{*}{$\begin{array}{l}\text { Regular exercise or any physical activity } \\
3 \text { or more times a week (yes) }\end{array}$} & 43 & 43 \\
\hline & Median & $\begin{array}{c}\text { Interquartile } \\
\text { range } \\
(Q 25-Q 75)\end{array}$ \\
\hline CD4 levels (cell/mm3) & 369 & $220-555$ \\
\hline Viral load (copies/ml) & 0 & $0-1303$ \\
\hline CD8 levels (cell/mm3) & 850 & $574-1151$ \\
\hline CD4/CD8 ratio & 0.35 & $0.23-0.69$ \\
\hline
\end{tabular}




\section{Results}

The baseline demographic characteristics of the 105 participants are shown in table 1. Most participants were men (73\%) with an average age of 40 years (range: 21-71 years). Participants had low education levels, with $73 \%$ not having completed high school. In addition, $63 \%$ reported being single and $35 \%$ unemployed.

\section{Exploratory factor analysis and reliability}

The Cronbach's alpha coefficients for the CES-D-20 were 0.92 and 0.94 for baseline and second interview, respectively, and these values did not change when excluding an item. The intraclass correlation coefficient was 0.81 (95\% Cl: 0.72-0.88). Exploratory factorial analysis revealed four factors (table 2). The first factor explained $42.5 \%$ of the variance; the second, $9 \%$; the third, $7 \%$, and the fourth, $5 \%$. With the exception of item 2 ("I did not feel like eating, my appetite was poor"), all items loaded distinctly with factor loadings in the range of $0.50-0.80$. Five items did not load in the same dimension as in the original scale: items 7,11 , and 20 , which are somatic dimensions, item 12, related to positive affect, and item 13, related to interpersonal dimension. The Cronbach's alpha was good for factor 1 but was $<0.8$ for the other three factors. The exploratory factor analysis for the CES-D-10 revealed that one factor explained $50 \%$ of the variance, and the second factor, $11 \%$. The second factor only included item 8; the Cronbach's alpha was 0.89 for the first factor with the nine items.

Table 2. Rotated factor loadings for 20 - and 10 -item CES-D scale versions (pattern matrix)

\begin{tabular}{|c|c|c|c|c|c|c|}
\hline \multirow[b]{2}{*}{ Item } & \multicolumn{4}{|c|}{ CES-D 20} & \multicolumn{2}{|c|}{ CES-D 10} \\
\hline & Factor I & Factor II & Factor III & Factor IV & Factor I & Factor II \\
\hline $\begin{array}{l}\text { 1. I was bothered by things that do not usually bother me. (S) Me } \\
\text { molestaron cosas que usualmente no me molestan }\end{array}$ & & & $0.62^{*}$ & & 0.56 & \\
\hline $\begin{array}{l}\text { 3. I felt that I could not shake off the blues even with the help of my } \\
\text { family and friends. (D) Me sentía que no podía quitarme de encima la } \\
\text { tristeza, aun con la ayuda de mi familia o amigos. }\end{array}$ & $0.80^{*}$ & & & & & \\
\hline $\begin{array}{l}\text { 5. I had trouble keeping my mind on what I was doing. (S) Tenía } \\
\text { dificultad en concentrarme en lo que estaba haciendo. }\end{array}$ & & & $0.50^{*}$ & & 0.70 & \\
\hline $\begin{array}{l}\text { 6. I felt depressed. (D) Me sentía deprimido(a). } \\
\text { 7. I felt that everything I did was an effort. (S) Sentía que todo lo que } \\
\text { hacía era un esfuerzo. }\end{array}$ & $\begin{array}{l}0.85^{*} \\
0.65\end{array}$ & & & & $\begin{array}{l}0.83 \\
0.78\end{array}$ & \\
\hline $\begin{array}{l}\text { 8. I felt hopeful about the future. (P) Me sentía optimista sobre el futuro. } \\
\text { un f thought my life had been a failure. (D) Pensé que mi vida había sido } \\
\text { un fraca. }\end{array}$ & $0.69^{*}$ & & & $0.50^{*}$ & & 0.82 \\
\hline $\begin{array}{l}\text { 16. I enjoyed life. (P) Disfrutaba de la vida. } \\
\text { 17. I had crying spells. (D) Pasaba ratos llorando. }\end{array}$ & $0.61^{*}$ & & & $0.64^{*}$ & & \\
\hline $\begin{array}{l}\text { 18. I felt sad. (D) Me sentía triste. } \\
\text { 19. I felt that people disliked me. (I) Sentía que no le caía bien a la gente }\end{array}$ & $0.75^{\star}$ & $0.75^{\star}$ & & & & \\
\hline 20. I could not get going. (S) No tenía ganas de hacer nada. & 0.55 & 0.50 & & & 0.72 & \\
\hline Cronbach's alpha & 0.93 & 0.75 & 0.64 & 0.64 & 0.88 & \\
\hline
\end{tabular}

(S): Somatic; (D): Depressed; (P): Positive, and (I) Interpersonal, as per original scale method: Principal-component factors; Rotation: Orthogonal varimax. Kaiser-Meyer-Olkin measure of sampling adequacy was 0.8630 .

* Highest factor loading consistent with the highest factor loading in the original structure 
Table 3. Confirmatory factor analysis of the CES-D 20 and CES-D 10 scales

\begin{tabular}{lccccc}
\hline Model & $\begin{array}{c}\text { Original } \\
\text { 20-CES-D } \\
\text { factor } \\
\text { solution }\end{array}$ & $\begin{array}{c}\text { Factor solution } \\
\text { of table 2 }\end{array}$ & $\begin{array}{c}\text { Factor solution } \\
\text { of table 2 } \\
\text { without item 2 }\end{array}$ & $\begin{array}{c}\text { CES-D 10 } \\
\text { one factor }\end{array}$ & $\begin{array}{c}\text { Excluding } \\
\text { item 8 }\end{array}$ \\
\hline CFI & 0.827 & 0.84 & 0.85 & 0.95 & 0.96 \\
TLI & 0.799 & 0.81 & 0.83 & 0.94 & 0.95 \\
SRMR & 0.08 & 0.08 & 0.08 & 0.05 & 0.05 \\
RMSEA & 0.10 & 0.09 & 0.10 & 0.08 & 0.07 \\
\hline
\end{tabular}

CFI Comparative fit index; TLI: Tucker-Lewis index; SRMR: Standardised root mean square residual; RMSEA: Root mean square error of approximation

\section{Confirmatory factor analysis}

Table 3 summarizes the model fit of statistics for different factor solutions. The best fit was obtained with the CES-D-10 scale, either with or without item 8. The factor solution of the CES-D-20 of table 2 and the original scale factor solution did not meet the criteria for goodness to fit of the model (table 3).

\section{Item response analysis}

Four of the items of the CES-D-20 failed the test of fit (item-fit statistics for a multidimensional model). Poorly fitting items should be expected with the significance $<0.05$, to diagnose where the functional form of the item response theory analysis model was incorrectly specified: $3(p=0.040), 6$ $(p=0.038), 9(p=0.036)$ and $13(p=0.050)$. In the CES-D-10 scale, only item 5 failed to demonstrate unacceptable fit ( $p=0.007)$. Items 4,8 , and 13 in the CES-D-20 and item 8 in the CES-D-10 did not show acceptable discrimination values (how well items identify patients at different levels of depression).

\section{Correlates of depression}

Of the participants, $54.3 \%$ (95\% Cl: $44.6-64.0)$ had CES-D scores of $\geq 16$, $44.8 \%$ (95\% Cl: $35.1-54.4$ ) had CES-D scores of $\geq 20$ with the 20 item scale, and $53.3 \%(95 \% \mathrm{Cl}: 43.6-63.0)$ had CES-D scores of $\geq 10$ with the 10 -item scale. The relationships between the exposure and the presence of depressive symptoms were consistent across the different cut-off points used (table 4). A score over the cut-off points (either $\geq 16$ or $\geq 20$ in the CES-D-20, or $\geq 10$ in the CES-D-10) was more frequent among women, housewives, the unemployed, and among those with dissatisfaction regarding housing and those who did not exercise. When using the cut-off point of $\geq 16$, we found an association with smoking which did not occur when using the other two cut-off points (table 4). A higher viral load and lower $C D_{4}$ levels were found in those with possible depression and this was consistent with all three CES-D versions (table 5).

\section{Discussion}

The adaptation and use of the CES-D scale were felt to be an important tool in the clinical assessment of people living with HIV/AIDS, a population with special social and clinical characteristics that differ from those of the general adult population in Colombia. Ours is the first study in Colombian people living with HIV/AIDS examining the validity and reliability of both the 20 item and the 10 item versions of the CES-D scale.

The application of this scale in our sample was straightforward and subjects were eager to answer all questions, which resulted in no missing data.

The long scale demonstrated high internal reliability suggesting that the 20 items measured the same underlying construct: depressive symptoms. It also showed a high construct validity as it correlated with known established 
Table 4. General characteristics of participants according to CES-D scores

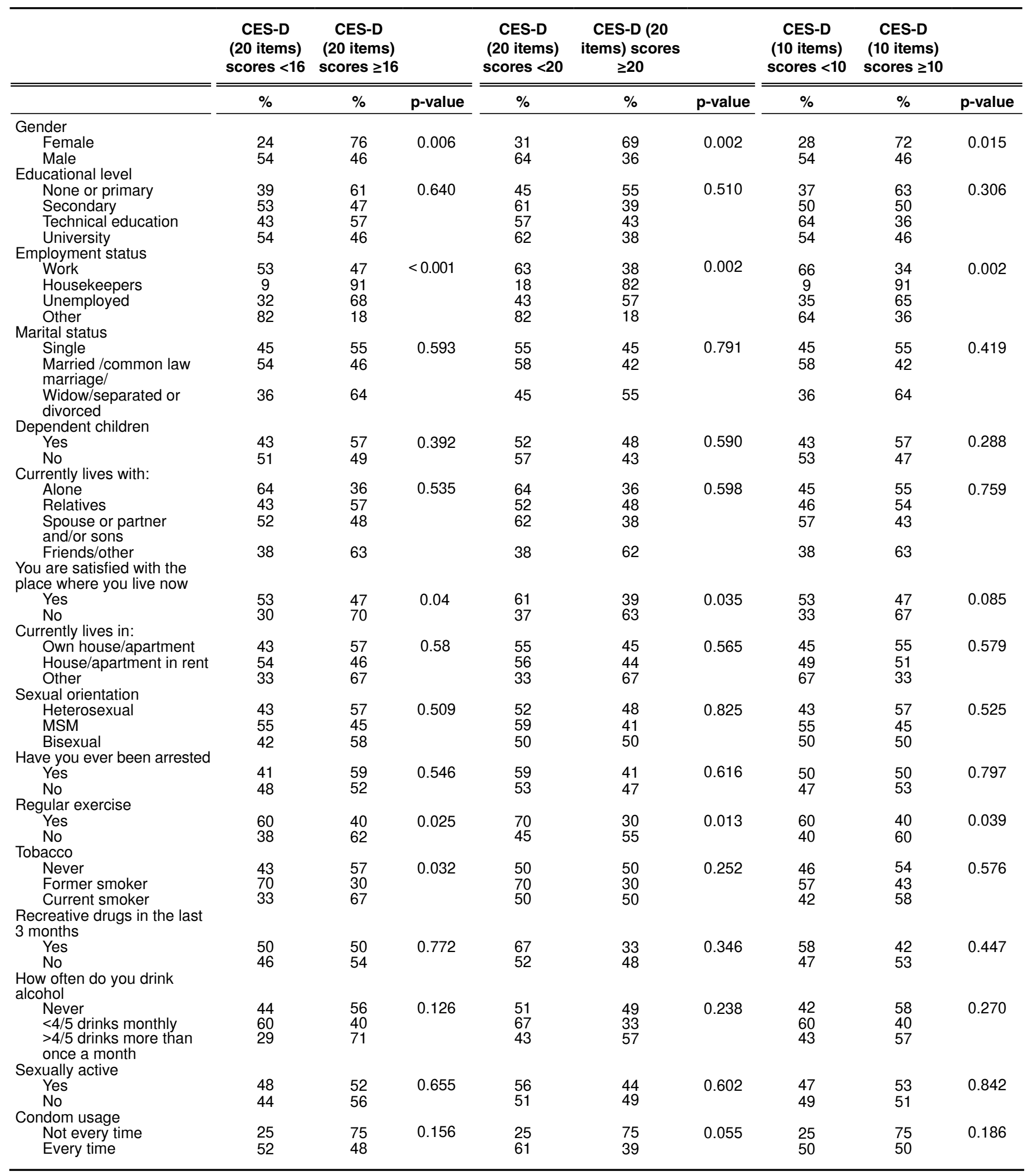


Table 5. Immunology and virology distributions by CES-D scores

\begin{tabular}{|c|c|c|c|c|c|c|c|c|c|}
\hline & $\begin{array}{l}\text { CES-D (20 items) } \\
\text { scores }<16\end{array}$ & $\begin{array}{l}\text { CES-D (20 items) } \\
\text { scores } \geq 16\end{array}$ & & $\begin{array}{l}\text { CES-D (20 items) } \\
\text { scores }<20\end{array}$ & $\begin{array}{l}\text { CES-D (20 items) } \\
\text { scores } \geq 20\end{array}$ & & $\begin{array}{l}\text { CES-D (10 items) } \\
\text { scores }<10\end{array}$ & $\begin{array}{l}\text { CES-D (10 items) } \\
\text { scores } \geq 10\end{array}$ & \\
\hline & $\begin{array}{c}\text { Median } \\
\text { (range IQ) }\end{array}$ & $\begin{array}{l}\text { Median } \\
\text { (range IQ) }\end{array}$ & $\mathbf{p}$ & $\begin{array}{c}\text { Median } \\
\text { (range IQ) }\end{array}$ & $\begin{array}{c}\text { Median } \\
\text { (range IQ) }\end{array}$ & $\mathbf{p}$ & $\begin{array}{c}\text { Median } \\
\text { (range IQ) }\end{array}$ & $\begin{array}{c}\text { Median } \\
\text { (range IQ) }\end{array}$ & $\mathbf{p}$ \\
\hline Age & $39.5(30-46)$ & $40(34-45)$ & 0.5914 & $39(30-46)$ & $41(34-46)$ & 0.5551 & $39(30-45)$ & $41(34-47)$ & 0.1476 \\
\hline $\mathrm{CD}_{4}$ & $425(319-591)$ & $324.5(189-458)$ & 0.0206 & $423(304-589)$ & $316(189-434)$ & 0.0229 & $434(322-589)$ & $316(189-440)$ & 0.0137 \\
\hline Viral load & $0(0-675564)$ & $58.5(0-21412)$ & 0.0373 & $0(0-328)$ & $114(0-21412)$ & 0.0221 & $0(0-66)$ & $95(0-21412)$ & 0.0066 \\
\hline CD8 & 925 (678-1162) & 766.5 (537-1113) & 0.0835 & $918(636-1289)$ & 755 (537-1078) & 0.0497 & 939 (652-1289) & $778(540-1107)$ & 0.0772 \\
\hline $\begin{array}{l}\mathrm{CD}_{4} / \mathrm{CD}_{8} \\
\text { ratio }\end{array}$ & $0.489(0.287-0.657)$ & $0.323(0.213-0.712)$ & 0.1922 & $0.457(0.280-0.657)$ & $0.327(0.213-0.712)$ & 0.3285 & $0.518(0.280-0.657)$ & $0.327(0.213-0.712)$ & 0.1824 \\
\hline
\end{tabular}

factors for depression, such as gender, low socio-economic status, and smoking. However, our factor analysis showed that 5 of the 20 items did not load in the original scale factor loadings. Similar findings have been reported in previous validation studies in which the original four dimensions in the CES-D scale did not hold for people living with HIV/AIDS (37). Our factor analysis failed to confirm the model fit in the factor solution of the 20 item version, and the item response theory analysis established that four items did not meet the criteria for a good fit. Thus, the usefulness of the total score of the CES-D in people living with HIV/AIDS should be approached with caution. In contrast, the CES-D-10 appeared to work better in our sample population as it showed high internal consistency and a valid factorial structure. The usefulness of this shorter CES-D scale has also been found by other studies (38).

It has been documented that the CES-D scale has a factorial structure that behaves inconsistently in different populations including people living with HIV/AIDS $(25,31,37)$. Some authors have found a different factorial structure when using the oblique rotation (24). We found that the oblique rotation was no better than that obtained with varimax (data not shown). In a clinical sample of 350 people living with HIV/AIDS, Gay, et al. (37) found that items $2,4,8,11$, and 16 , which are mostly related to positive affect, were problematic and caused the scale to lose validity. In our study, we found that item 8 was also problematic. Some authors have even recommended to fully exclude positive affect items from the CES-D $(31,39)$. Furthermore, we found four different items with poor fit: items $3,6,9$, and 13, which mainly relate to depressive state and seem to load differently according to other reports (40). Since the CES-D-10 scale did not include items 3, 9 and 13, this may explain why in our population it held its validity.

It has been suggested that the somatic symptoms among HIV positive participants are difficult to interpret as they may overlap with medication side effects or with the effects of HIV infection itself (30). Other studies have found that those items are more likely to load in different factors (41). In fact, four of the items that did not load in the same factor as the original scale in our sample were related to somatic symptoms (items 2, 7, 11, and 20). Interestingly, items 7,11 , and 20 loaded well on the CES-D-10 scale. Even shorter versions of the scale have been found to be valid in general populations (22). One version has seven items of which five are also included in the CES-D-10 that we studied. Thus, it is possible that somatic symptoms are not as problematic in populations of people living with HIV/AIDS in Colombia.

There was a high frequency of depressive symptoms in our sample and we found that social factors such as gender, housing satisfaction, unemployment, as well as smoking, were associated with more depressive 
symptoms in our sample. In addition, $60 \%$ of the women had high levels of depressive symptoms, which is consistent with a disproportionate prevalence of depression found in females living with HIV/AIDS in other studies $(14,42,43)$ which suggest that the combination of depression with poverty, interpersonal violence, and the burden of caring for themselves and others creates numerous social challenges for women living with HIV $(14,44,45)$.

In this regard, it is conceivable that the 'caregiver' role that many Colombian women play (household tasks and raising children) can result in a high burden of stressful experiences $(46,47)$. The coexistence of depression and smoking is well established in people living with HIV $(48,49)$ which calls for interventions to address both conditions simultaneously. Studies have documented the association between disease severity as measured by $\mathrm{CD}_{4}$ counts and depressive symptoms (14,50) an aspect that was also evidenced in the small sample of people living with HIV/AIDS under study.

We have not validated the CES-D against gold standards for the diagnosis of depressive disorders. A previous study in Colombia found that the 20-point cut-off in the CES-D scale was better for depression in the general population; future studies in the country should consider confirming the factor structure and fit of the CES-D-20 scale with a more advanced item response theory analysis (51) and assess the accuracy of the full and shortened versions of this scale in people living with HIV/AIDS. Oversampling of women and transgender populations should be considered in those previous studies since one of them showed differences in item functions in those populations (37). Our sample size limited the possibility of assessing differences in item responses in such populations.

The CES-D scale has been extensively used worldwide and will likely continue to be used in future assessments of depressive symptoms in people living with HIV/AIDS. The subjective nature of this scale for the assessment of depressive symptoms may have resulted in an underestimation of the prevalence of depression due to social desirability bias. However, we believe that overestimation is more likely to occur than lack of validity in people living with HIV/AIDS given the lack of fit of some of the items reported. However, even with such overestimation, the CES-D-10 scale can be a valid tool for the screening of depression and its use may effectively help select people living with HIV/AIDS who need a more detailed assessment and, eventually, treatment for depression.

\section{Acknowledgments}

We would like to thank our participants and Dr. Louise Balfour from the University of Ottawa for her important input in the design and development of this project.

\section{References}

1. Murray CJ, López AD. Alternative projections of mortality and disability by cause 1990-2020: Global Burden of Disease Study. Lancet. 1997;349:1498-504. https://doi.org/10.1016/ S0140-6736(96)07492-2

2. Moussavi S, Chatterji S, Verdes E, Tandon A, Patel V, Ustun B. Depression, chronic diseases, and decrements in health: Results from the World Health Surveys. Lancet. 2007;370:851-58. https://doi.org/10.1016/S0140-6736(07)61415-9

3. Ferrari AJ, Charlson FJ, Norman RE, Patten SB, Freedman G, Murray CJ, et al. Burden of depressive disorders by country, sex, age, and year: Findings from the global burden of disease study 2010. PLoS Med. 2013;10:e1001547. https://doi.org/10.1371/journal. pmed. 1001547 
4. Kessler RC, McGonagle KA, Zhao S, Nelson CB, Hughes M, Eshleman S, et al. Lifetime and 12-month prevalence of DSM-III-R psychiatric disorders in the United States: Results from the National Comorbidity Survey. Arch Gen Psychiatry. 1994; 51:8-19. https://doi.org/10.1001/archpsyc.1994.03950010008002

5. Bing EG, Burnam MA, Longshore D, Fleishman JA, Sherbourne CD, London AS, et al. Psychiatric disorders and drug use among human immunodeficiency virus--infected adults in the United States. Arch Gen Psychiatry. 2001;58:721-8. https://doi.org/10.1001/archpsyc.58.8.721

6. Williams P, Narciso L, Browne G, Roberts J, Weir R, Gafni A. The prevalence, correlates, and costs of depression in people living with HIV/AIDS in Ontario: Implications for service directions. AIDS Educ Prev. 2005;17:119-30. https://doi.org/10.1521/aeap.17.3.119.62903

7. Chikezie U, Otakpor A, Kuteyi O, James B. Depression among people living with human immunodeficiency virus infection/acquired immunodeficiency syndrome in Benin City, Nigeria: A comparative study. Niger J Clin Pract. 2013;16:238-42. https://doi.org/10.4103/11193077.110148

8. Silveira MP, Guttier MC, Pinheiro CA, Pereira TV, Cruzeiro AL, Moreira LB. Depressive symptoms in HIV-infected patients treated with highly active antiretroviral therapy. Rev Bras Psiquiatr. 2012;34:162-7. https://doi.org/10.1590/S1516-44462012000200008

9. Mello VA, Segurado AA, Malbergier A. Depression in women living with HIV: Clinical and psychosocial correlates. Arch Womens Ment Health. 2010;13:193-9. https://doi.org/10.1007/ s00737-009-0094-1

10. Wu DY, Muñoz M, Espiritu B, Zeladita J, Sánchez E, Callacna M, et al. Burden of depression among impoverished HIV-positive women in Perú. J Acquir Immune Defic Syndr. 2008;48:500-4. https://doi.org/10.1097/QAl.0b013e31817dc3e9

11. Bouhnik AD, Préau M, Vincent E, Carrieri MP, Gallais H, Lepeu G, et al. Depression and clinical progression in HIV-infected drug users treated with highly active antiretroviral therapy. Antivir Ther. 2005;10:53-61.

12. Lima VD, Geller J, Bangsberg DR, Patterson TL, Daniel M, Kerr T, et al. The effect of adherence on the association between depressive symptoms and mortality among HIVinfected individuals first initiating HAART. AIDS. 2007;21:1175-83. https://doi.org/10.1097/ QAD.0b013e32811ebf57

13. Hartzell JD, Spooner K, Howard R, Wegner S, Wortmann G. Race and mental health diagnosis are risk factors for highly active antiretroviral therapy failure in a military cohort despite equal access to care. J Acquir Immune Defic Syndr. 2007;44:411-6. https://doi.org/10.1097/QAl.0b013e31802f83a6

14. Ickovics JR, Hamburger ME, Vlahov D, Schoenbaum EE, Schuman P, Boland RJ, et al. Mortality, CD4 cell count decline, and depressive symptoms among HIV-seropositive women: Longitudinal analysis from the HIV Epidemiology Research Study. JAMA. 2001;285:1466-74. https://doi.org/10.1001/jama.285.11.1466

15. Ironson G, O’Cleirigh C, Fletcher MA, Laurenceau JP, Balbin E, Klimas N, et al. Psychosocial factors predict CD4 and viral load change in men and women with human immunodeficiency virus in the era of highly active antiretroviral treatment. Psychosom Med. 2005;67:1013-21. https://doi.org/10.1097/01.psy.0000188569.58998.c8

16. Trépanier LL, Rourke SB, Bayoumi AM, Halman MH, Krzyzanowski S, Power C. The impact of neuropsychological impairment and depression on health-related quality of life in HIV-infection. J Clin Exp Neuropsychol. 2005;27:1-15. https://doi. org/10.1080/138033990513546

17. Bayón C, Ribera E, Cabrero E, Griffa L, Burgos Á. Prevalence of depressive and other central nervous system symptoms in HIV-infected patients treated with HAART in Spain. J Int Assoc Physicians AIDS Care (Chic). 2012;11:321-8. https://doi. org/10.1177/1545109712448217

18. Villes V, Spire B, Lewden C, Perronne C, Besnier JM, Garré M, et al. The effect of depressive symptoms at ART initiation on HIV clinical progression and mortality: Implications in clinical practice. Antivir Ther. 2007;12:1067-74.

19. Nokes KM, Kendrew J. Correlates of sleep quality in persons with HIV disease. J Assoc Nurses AIDS Care. 2001;12:17-22. https://doi.org/10.1016/S1055-3290(06)60167-2

20. Villalobos-Galvis FH, Ortiz-Delgado L. Características psicométricas de la escala CES-D en adolescentes de San Juan de Pasto (Colombia). Avances en Psicología Latinoamericana. 2012;30:328-40. 
21. Camacho PA, Rueda-Jaimes GE, Latorre JF, Navarro-Mancilla ÁA, Escoba M, Franco JA. Validez y confiabilidad de la escala del Center for Epidemiologic Studies-Depression en estudiantes adolescentes de Colombia. Biomédica. 2009;29:260-9. https://doi.org/10.7705/ biomedica.v29i2.28

22. Rueda-Jaimes GE, Díaz-Martínez LA, López-Camargo MT, Campo-Arias A. Validación de una versión abreviada de la Escala para Depresión del Centro de Estudios Epidemiológicos (CES-D) en adultos colombianos. Revista Colombiana de Psiquiatría. 2009;38:513-21.

23. Radloff LS. The CES-D scale: A self-report depression scale for research in the general population. Applied Psychological Measurement. 1977;1:385-401. https://doi. org/10.1177/014662167700100306

24. Privado J, Garrido J. Factorial structure of the Spanish center for epidemiologic studies depression scales in HIV patients. Community Ment Health J. 2013;49:492-7. https://doi. org/10.1007/s10597-013-9618-2

25. Chishinga N, Kinyanda E, Weiss HA, Patel V, Ayles H, Seedat S. Validation of brief screening tools for depressive and alcohol use disorders among TB and HIV patients in primary care in Zambia. BMC Psychiatry. 2011;11:75.https://doi.org/10.1186/1471$244 \mathrm{X}-11-75$

26. Natamba BK, Achan J, Arbach A, Oyok TO, Ghosh S, Mehta S, et al. Reliability and validity of the center for epidemiologic studies-depression scale in screening for depression among HIV-infected and -uninfected pregnant women attending antenatal services in northern Uganda: A cross-sectional study. BMC Psychiatry. 2014;14:303. https://doi. org/10.1186/s12888-014-0303-y

27. Thai TT, Jones MK, Harris LM, Heard RC. Screening value of the Center for epidemiologic studies--depression scale among people living with HIV/AIDS in Ho Chi Minh City, Vietnam: A validation study. BMC Psychiatry. 2016;16:145. https://doi.org/10.1186/s12888-016-0860$\underline{3}$

28. Akena D, Joska J, Obuku EA, Stein DJ. Sensitivity and specificity of clinician administered screening instruments in detecting depression among HIV-positive individuals in Uganda. AIDS Care. 2013;25:1245-52. https://doi.org/10.1080/09540121.2013.764385

29. Zhang W, O'Brien N, Forrest JI, Salters KA, Patterson TL, Montaner JS, et al. Validating a shortened depression scale (10 item CES-D) among HIV-positive people in British Columbia, Canada. PloS One. 2012;7:e40793. https://doi.org/10.1371/journal.pone.0040793

30. Kalichman SC, Rompa D, Cage M. Distinguishing between overlapping somatic symptoms of depression and HIV disease in people living with HIV-AIDS. J Nerv Ment Dis. 2000;188:662-70.

31. Stansbury JP, Ried LD, Velozo CA. Unidimensionality and bandwidth in the Center for Epidemiologic Studies Depression (CES--D) scale. J Pers Assess. 2006;86:10-22. https:// doi.org/10.1207/s15327752jpa8601 03

32. Adams LM, Wilson TE, Merenstein D, Milam J, Cohen J, Golub ET, et al. Using the Center for Epidemiologic Studies Depression Scale to assess depression in women with HIV and women at risk for HIV: Are somatic items invariant?. Psychol Assess. 2018;30:97105. https://doi.org/10.1037\%2Fpas0000456

33. Borsa JC, Damásio BF, Bandeira DR. Cross-cultural adaptation and validation of psychological instruments: some considerations. Paidéia (Ribeirão Preto). 2012;22:423-32. https://doi.org/10.1590/S0103-863X2012000300014

34. Leykin Y, Torres LD, Aguilera A, Muñoz RF. Factor structure of the CES-D in a sample of Spanish-and English-speaking smokers on the Internet. Psychiatry Res. 2011;185:269-74. https://doi.org/10.1016/j.psychres.2010.04.056

35. Bojorquez I, Salgado N. Características psicométricas de la Escala Center for Epidemiological Studies-depression (CES-D), versiones de 20 y 10 reactivos, en mujeres de una zona rural mexicana. Salud Mental. 2009;32:299-307.

36. Hu Lt, Bentler PM. Cutoff criteria for fit indexes in covariance structure analysis: Conventional criteria versus new alternatives. Struct Equ Modeling. 1999;6:1-55. https://doi. org/10.1080/10705519909540118

37. Gay CL, Kottorp A, Lerdal A, Lee KA. Psychometric limitations of the Center for Epidemiologic Studies-Depression Scale for assessing depressive symptoms among adults with HIV/AIDS: a Rasch analysis. Depress Res Treat. 2016;2016:2824595. https://doi. org/10.1155/2016/2824595 
38. Mohebbi M, Nguyen V, McNeil J, Woods R, Nelson M, Shah R, et al. Psychometric properties of a short form of the Center for Epidemiologic Studies Depression (CES-D-10) scale for screening depressive symptoms in healthy community dwelling older adults. Gen Hosp Psychiatry. 2017;51:118-25. https://doi.org/10.1016/j.genhosppsych.2017.08.002

39. Schroevers MJ, Sanderman R, van Sonderen E, Ranchor AV. The evaluation of the Center for Epidemiologic Studies Depression (CES-D) scale: Depressed and positive affect in cancer patients and healthy reference subjects. Qual Life Res. 2000;9:1015-29.

40. Carleton RN, Thibodeau MA, Teale MJ, Welch PG, Abrams MP, Robinson T, et al. The center for epidemiologic studies depression scale: A review with a theoretical and empirical examination of item content and factor structure. PloS One. 2013;8:e58067. https://doi. org/10.1371/journal.pone.0058067

41. Crockett LJ, Randall BA, Shen YL, Russell ST, Driscoll AK. Measurement equivalence of the center for epidemiological studies depression scale for Latino and Anglo adolescents: A national study. J Consult Clin Psychol. 2005;73:47-58. https://doi.org/10.1037\%2F0022$006 \times .73 .1 .47$

42. Aljassem K, Raboud JM, Hart TA, Benoit A, Su D, Margolese SL, et al. Gender differences in severity and correlates of depression symptoms in people living with HIV in Ontario, Canada. J Int Assoc Provid AIDS Care. 2016;15:23-35. https://doi. org/10.1177/2325957414536228

43. Cook J, Cohen M, Burke J, Grey D, Anastos K, Kirstein L, et al. Effects of depressive symptoms and mental health quality of life on use of highly active antiretroviral therapy among HIV-seropositive women. J Acquir Immune Defic Syndr. 2002;30:401-9. https://doi. org/10.1097/01.QAl.0000018280.16783.FE

44. Vlahov D, Wientge D, Moore J, Flynn C, Schuman P, Schoenbaum E, et al. Violence among women with or at risk for HIV infection. AIDS Behav. 1998;2:53-60. https://doi. org/10.1023/A:1022359307814

45. Moore J, Schuman P, Schoenbaum E, Boland B, Solomon L, Smith D. Severe adverse life events and depressive symptoms among women with, or at risk for, HIV infection in four cities in the United States of America. AIDS. 1999;13:2459-68.

46. Gurung RA, Taylor SE, Kemeny M, Myers H. "HIV is not my biggest problem": The impact of HIV and chronic burden on depression in women at risk for AIDS. J Soc Clin Psychol. 2004;23:490-511. https://doi.org/10.1521/jscp.23.4.490.40305

47. Varela-Arévalo MT, Gómez OL, Mueses-Marín HF, Quintero-Galindo J, Tello-Bolívar IC. Factores relacionados con la adherencia al tratamiento farmacológico para el VIH/SIDA. Salud Uninorte. 2013;29:83-95.

48. Vickers KS, Patten CA, Lane K, Clark MM, Croghan IT, Schroeder DR, et al. Depressed versus nondepressed young adult tobacco users: Differences in coping style, weight concerns and exercise level. Health Psychol. 2003;22:498-503. https://doi.org/10.1037\% 2F0278-6133.22.5.498

49. Mimiaga MJ, Reichmann WM, Safren SA, Losina E, Arbeláez C, Walensky RP. Prevalence and correlates of clinically significant depressive symptoms in an urban hospital emergency department. Prim Care Companion J Clin Psychiatry. 2010;12:e1-e11. https:// doi.org/10.4088/PCC.09m00817gry

50. Kaharuza FM, Bunnell R, Moss S, Purcell DW, Bikaako-Kajura W, Wamai N, et al. Depression and CD4 cell count among persons with HIV infection in Uganda. AIDS Behav. 2006;10(Suppl.):S105-S11. https://doi.org/10.1007\%2Fs10461-006-9142-2

51. Alexandrowicz RW, Jahn R, Wancata J. Assessing the dimensionality of the CES-D using multi-dimensional multi-level Rasch models. PloS One. 2018;13:e0197908. https://doi. org/10.1371/journal.pone.0197908 
Appendix: Spanish version of the CES-D scale used in the study

Instrucciones: Las siguientes son preguntas relacionadas con su estado de ánimo. Hay una lista de maneras en la que usted pudo haberse sentido o comportado en la última semana. Por favor, indique con qué frecuencia se sintió de esta manera.

\begin{tabular}{|c|c|c|c|c|}
\hline Durante la semana pasada... & $\begin{array}{c}\text { Raramente } 0 \\
\text { ninguna vez } \\
\text { (<1 día) }\end{array}$ & $\begin{array}{c}\text { Una parte o un } \\
\text { poco de tiempo } \\
\text { (1-2 días) }\end{array}$ & $\begin{array}{l}\text { Ocasionalmente } \\
\text { o una cantidad } \\
\text { moderada de } \\
\text { tiempo (3-4 días) }\end{array}$ & $\begin{array}{c}\text { La mayoría o } \\
\text { todo el tiempo } \\
\text { (5-7 días) }\end{array}$ \\
\hline $\begin{array}{l}\text { 1. Me molestaron cosas que usualmente } \\
\text { me molestan. }\end{array}$ & & & & \\
\hline $\begin{array}{l}\text { 2. No me sentía con ganas de comer; ten } \\
\text { mal apetito. }\end{array}$ & & & & \\
\hline $\begin{array}{l}\text { 3. Me sentía que no podía quitarme de } \\
\text { encima la tristeza, aun con la ayuda de } \mathrm{m} \\
\text { familia o amigos. }\end{array}$ & & & & \\
\hline $\begin{array}{l}\text { 4. Sentía que yo era tan bueno(a) como } \\
\text { cualquier otra persona. }\end{array}$ & & & & \\
\hline $\begin{array}{l}\text { 5. Tenía dificultades en concentrarme en } \\
\text { que estaba haciendo. }\end{array}$ & & & & \\
\hline 6. Me sentía deprimido(a). & & & & \\
\hline $\begin{array}{l}\text { 7. Sentía que todo lo que hacía era un } \\
\text { esfuerzo. }\end{array}$ & & & & \\
\hline 8. Me sentía optimista sobre el futuro. & & & & \\
\hline 9. Pensé que mi vida había sido un fraca & & & & \\
\hline 10. Me sentía con miedo. & & & & \\
\hline 11. Mi sueño era inquieto. & & & & \\
\hline 12. Estaba contento(a). & & & & \\
\hline 13. Hablaba menos de lo usual. & & & & \\
\hline 14. Me sentía solo(a). & & & & \\
\hline 15. La gente no era amistosa. & & & & \\
\hline 16. Disfrutaba de la vida. & & & & \\
\hline 17. Pasaba ratos llorando. & & & & \\
\hline 18. Me sentía triste. & & & & \\
\hline 19. Sentía que no le caía bien a la gente. & & & & \\
\hline 20. No tenía ganas de hacer nada. & & & & \\
\hline
\end{tabular}

